\title{
EDITORIAL \\ Escherichia coli-Related Diseases in Latin America Remain in the Spotlight: the Brazilian Efforts to Understand $E$. coli Pathogenesis
}

\author{
Alfredo Torres*
}

\begin{abstract}
Department of Microbiology and Immunology, Department of Pathology and Sealy Center for Vaccine Development, University of Texas Medical Branch, Galveston, Texas 77555-1070, USA
\end{abstract}

Although the $21^{\text {st }}$ century has seen significant changes in health care reforms and practices, and has experienced quick progression in the understanding of infectious diseases, diarrhea caused by enteric infections is a major factor in morbidity and mortality worldwide and it is estimated 2-4 billion episodes of infectious diarrhea occur each year and are especially prevalent in infants. Further, diarrhea as well as other infections associated with different pathogenic Escherichia coli strains continue to be a health problem in some tropical and subtropical areas and are one of the leading causes of disease and death in humans and animals [1]. In Latin America, infectious disease research, as well as basic and applied science in general, is receiving significant attention, despite many challenges that the scientific community are still facing in this region. In response to the significant increase in the number of scientific papers published by Latin American authors, governments (particularly those of Brazil, Argentina, Chile, and Mexico) have announced packages and incentives to foster science and technology [2].

A good example from incentives that have begun to deliver results are those made by the Brazilian government which in the past 15 years have increased the number of graduate school programs, support research centers of excellence, and to establish and to consolidate a national system for science, technology and innovation [2]. Apart from the country's estimated $7.5 \%$ economic growth in 2010 , efforts continue for the consolidation and expansion of research at traditional Universities and Institutes, allowing the investigators to partner with private investors and/or companies, advancing Research and Development [3], while promoting science and technology to Society.

The significant scientific advances currently happening in different Brazilian laboratories is represented in this mini

\footnotetext{
*Address correspondence to this author at the Department of Microbiology and Immunology, Department of Pathology and Sealy, Center for Vaccine Development, University of Texas Medical Branch, Galveston, Texas 77555-1070, USA; Tel: (409) 747 0189; Fax: (409) 747 6869;

E-mail: altorres@utmb.edu
}

hot topic issue entitled "Recent advances in the study of pathogenic Escherichia coli in Brazil". The issue highlights the diversity of research topics in the E. coli field currently explored in this country; including the identification of potentially virulent $E$. coli strains in parrots and parakeets; the discovery that different avian pathogenic $E$. coli subgroups are associated to a specific infectious syndrome in poultry; the characterization of different phenotypic characteristics of human pathogenic E. coli strains; and the importance of Shiga toxin-producing $E$. coli $\mathrm{O} 157$ as agents of Hemolytic Uremic Syndrome in Brazilian patients.

The highlighted research papers in this issue are part of a largest effort in Latin America by the pathogenic E. coli scientific community to foster long-standing continent-wide collaborations for the promotion and dissemination of their research and to educate and prepare the next generation of Latin American E. coli investigators. In response to this effort, the Latin American Coalition for Escherichia coli Research (LACER) was created, consisting of a multidisciplinary network of more than 60 international research groups working on pathogenic $E$. coli, with the ultimate goal of advancing our understanding and disseminating the $E$. coli research in this region. One of the fist accomplishments of LACER was the publication of an e-book that contains a comprehensive analysis of the most common categories of $E$. coli associated with diarrheal illness in Latin America [1]. As a second major effort to disseminate the research performed in specific laboratories in the region, the minihot topic issue in The Open Microbiology Journal became a reality.

\section{REFERENCES}

[1] Pathogenic Escherichia coli in Latin America. Bentham Science e-books. Torres, A.G. Editor. 2010. ISBN: 978-1-60805-192-2.

[2] Triunfol ML. Latin American science moves into the spotlight. Cell 2007; 131:1213-6.

[3] Rodrigues DG. Brazil: An emerging partner in drug R\&D. IDrugs 2009; 12:497-502.

(C) Alfredo Torres; Licensee Bentham Open.

This is an open access article licensed under the terms of the Creative Commons Attribution Non-Commercial License (http://creativecommons.org/licenses/_by-nc/3.0/) which permits unrestricted, non-commercial use, distribution and reproduction in any medium, provided the work is properly cited. 